Syntax Literate : Jurnal Ilmiah Indonesia p-ISSN: 2541-0849

e-ISSN : 2548-1398

Vol. 5, No. 3 Maret 2020

\title{
TORASTING (MOTOR ANTI STUNTING) SISTEM WIRAUSAHA UNTUK UPAYA PENCEGAHAN STUNTING DAN PEMBUKAAN LAPANGAN PEKERJAAN UNTUK MEWUJUDKAN TUJUAN PEMBANGUNAN BERKELANJUTAN DI DAERAH KUNINGAN
}

\section{Figih Pratama dan Atin Suhartini}

Universitas Islam Al-Ihya Kuningan

Email: pfigih26@gmail.com dan atinsuhartini401@gmail.com

\section{Abstract}

Sustainable development goals (SDGs) in the Indonesian language are the Sustainable Development Goals is a document of continued global development agreements of the Millennium Development Goals (MDGs) which began in September 2015 along with the end of the MDGs until 2030 with 17 goals oriented, among them, without poverty and without starving, for this paper aims to provide one of the ideas of the system to achieve several points from the 17 goals set by the United Nations namely to provide jobs for Micro, Small and Medium Enterprises (UMKM) for poverty reduction and prevention of stunting for toddlers. The UMKM idea system and food processing business from Moringa leaf flour can reduce the stunting percentage and poverty rate in Kuningan regency and this idea system is worthy of being a business after being tested for the feasibility of a food processing business from Moringa leaf flour.

Keywords: Moringa Leaves, Poverty, Stunting, Sustainable Development Goals (SDGs), Micro, Small and Medium Enterprises (UMKM).

\section{Abstrak}

Sustainable development goals (SDGs) dalam bahasa Indonesia adalah Tujuan Pembangunan berkelanjutan merupakan sebuah dokumen kesepakatan pembangunan global lanjutan dari Millenium Development Goals (MDGs) yang dimulai sejak September 2015 beriring dengan berakhirnya MDGs sampai dengan 2030 dengan berorientasi pada 17 tujuan diantaranya adalah tanpa kemiskinan dan tanpa kelaparan, untuk itu karya tulis ini bertujuan untuk memberikan salah satu gagasan sistem untuk mencapai beberapa point dari 17 tujuan yang telah ditetapkan oleh PBB yakni untuk memberikan lapangan pekerjaan Usaha Mikro Kecil Menengah (UMKM) untuk penuntasan angka kemiskinan dan pencegahan stunting bagi balita. Dengan sistem gagasan UMKM dan usaha olahan makanan dari tepung daun kelor dapat mengurangi persentasi stunting dan angka kemiskinan di kabupaten Kuningan serta sistem gagasan ini layak untuk dijadikan sebuah usaha setelah diuji kelayakan usaha olahan makanan dari tepung daun kelor.

Kata kunci : Daun Kelor, Kemiskinan, Stunting, Sustainable Development Goals (SDGs), Usaha Mikro Kecil Menengah (UMKM) 


\section{Pendahuluan}

Indonesia juga dikenal memiliki potensi sumber daya laut yang besar (Romulus, 2017). Peranan Pemerintah dalam mengelola sumber daya kelautan dan perikanan yang sangat berlimpah dituntut untuk melakukan terobosan-terobosan melalui penerapkan kebijakan strategis seperti pemberdayaan masyarakat nelayan (empowerment), merupakan kebijakan yang sangat penting karena terkait dengan upaya mensejahterakan masyarakat (Duradin, 2017).

Untuk mencapai kehidupan manusia yang lebih baik dari berbagai permasalahan yang menimpa banyak manusia di berbagai negara diperlukan solusi yang dirasa dapat menyelesaikan permasalahan tersebut, untuk itu PBB mendeklarasikan Tujuan Pembangunan Milenium atau Millenium Development Goals (MDGs) yang dimulai pada tahun 2000 dan selesai pada bulan September tahun 2015 dan berhasil membuat perubahan namun masih ada pekerjaan rumah (PR) beberapa permasalahan yang belum terselesaikan sehingga PBB mendeklarasikan kembali. Tujuan Pembangunan Berkelanjutan atau Sustainable Development Goals (SDGs) pada bulan September 2015 sebagai tujuan global sampai tahun 2030.

Dalam dua point yang menjadi orientasi dari tujuan pembangunan berkelanjutan daerah Kuningan dalam kondisi memprihatinkan diantaranya susahnya mencari lapangan pekerjaan sehingga menimbulkan banyaknya pengangguran dan memilih untuk menjadi perantauan mengadu nasib di ibu kota atau kota lain untuk mencari nafkah, dan juga stunting yang saat ini tengah menjadi permasalahan yang besar dalam dunia kesehatan di berbagai daerah di Indonesia terkhusus daerah Kuningan.

Berdasarkan data dari Badan Kependudukan dan Keluarga Berencana Nasional (BKKBN), di Jawa Barat sendiri tercatat ada 29,9\% atau 2,7 juta balita yang terkena stunting. Menurut Gubernur, ada 13 kabupaten di Jawa Barat yang akan diintervensi program stunting untuk lebih maksimal. Tiga belas daerah dengan penderita terbanyak di Jawa Barat yang disinggung Emil, antara lain Kabupaten Garut (43,2\%), Kabupaten Sukabumi (37,6\%), Kabupaten Cianjur (35,7\%), Kabupaten Tasikmalaya (33,3\%), Kabupaten Bandung Barat (34,2\%), Kabupaten Bogor (28,29\%), Kabupaten Bandung (40,7\%), Kabupaten Kuningan (42\%), Kabupaten Cirebon (42,47\%), Kabupaten Sumedang (41,08\%), Kabupaten Indramayu (36,12\%), Kabupaten Subang (40,47\%), dan Kabupaten Karawang (34,87\%) (Rizali, Nurhakim, Santoso, \& Novianti, 2019) Dan ternyata di Kuningan ada 10 Desa yang anak mengalami stunting (Mustawan, 2018).

Faktor penyebab stunting diantaranya adalah ketika ibu sedang hamil mengidap anemia, kurangnya asupan gizi pada saat balita, ibu mempunyai asupan gizi yang buruk selama menyusui, bayi tidak diberikan ASI eksklusif selama 6 bulan. Balita atau anak yang mengalami stunting akan mengalami perkembangan pertumbuhan yang buruk.

Selain beberapa hal yang telah disebutkan di atas, kurangnya pengetahuan ibu mengenai stunting biasanya dikarenakan kurangnya informasi, tidak peduli, masih mengacu pada mitos karena dilatarbelakangi pendidikan yang rendah kemiskinan juga dapat menjadi faktor penyebab terjadinya stunting pada balita. 
Persentase penduduk miskin di Kabupaten Kuningan masih terbilang tinggi, yaitu $13,59 \%$ pada tahun 2016. Angka ini masih jauh di atas persentase penduduk miskin Jawa Barat sebesar 8,77\% dan nasional sebesar 10,64\% (Indonesia, 1983) Dari data tersebut penghasilan warga miskin di kabupaten Kuningan masih dibawah garis batas minimum pengeluaran per kapita per bulan untuk memenuhi kebutuhan minimum makanan dan non makanan. Secara rinci, angka kemiskinan di Kuningan dapat dilihat dari tabel di bawah ini:

Tabel 1 Angka kemiskinan di Kabupaten Kuningan pada tahun 2012-2016

\begin{tabular}{cccccccc}
\hline No & Indikator & \multicolumn{7}{c}{ Angka Kemiskinan } \\
\cline { 3 - 8 } & & $\mathbf{2 0 1 2}$ & $\mathbf{2 0 1 3}$ & $\mathbf{2 0 1 4}$ & $\mathbf{2 0 1 5}$ & $\mathbf{2 0 1 6}$ & $\mathbf{2 0 1 7}$ \\
\hline $\mathbf{1}$ & Jumlah & 142.257 & 139.353 & 133.572 & 147.210 & 144.070 & \\
& $\begin{array}{c}\text { Penduduk } \\
\text { Miskin (000 } \\
\text { jiwa) }\end{array}$ & & & & & & \\
& $\mathbf{2}$ & & & & & \\
\hline & Garis & 245.476 & 261.858 & 271.015 & 276.154 & 289.901 & \\
\hline Kemiskinan & & & & & 13,59 & 13,27 \\
& $\begin{array}{c}\text { Persentase } \\
\text { Penduduk } \\
\end{array}$ & 13,70 & 13,34 & 12,72 & 13,97 & 13,59 & \\
\hline
\end{tabular}

Sumber: BPS 2016

Dari data tabel angka kemiskinan di atas dapat dilihat bahwa penurunan angka kemiskinan di kabupaten Kuningan belum signifikan, dari tahun 2012-2016 penurunan angka kemiskinan hanya berkisar $0.11 \%$.

Karya tulis ini ditujukan untuk menyumbangkan aspirasi sebagai solusi untuk pengurangan stunting dan angka kemiskinan di kabupaten Kuningan dengan pengenalan makanan superfood atau makanan bergizi tinggi namun disajikan dalam bentuk makanan yang disukai oleh semua usia dari balita hingga dewasa dan dapat dijadikan sebuah UMKM yang dapat membuka lapangan pekerjaan bagi masyarakat kabupaten Kuningan serta untuk mencapai Tujuan Pembangunan Berkelanjutan atau Sustainable Development Goals (SDGs) 2030.

\section{Metode Penelitian}

Artikel ini menggunakan Metode data sekunder. Data sekunder adalah data yang diperoleh melalui buku, bukti yang telah ada, atau arsip baik yang dipublikasikan maupun yang tidak dipublikasikan secara umum. Metode ini lebih mudah di dapatkan dan menghemat waktu pengerjaan. Artikel dan informasi dari sumber situs yang jelas dikumpulkan untuk mencukupi kebutuhan informasi mengenai penelitian yang akan dibahas di artikel ini.

Disusulkan gagasan terpadu antara superfood dan UMKM sebagai upaya untuk mengurangi persentasi balita stunting di kabupaten Kuningan dan penghapusan angka kemiskinan di kabupaten Kuningan serta upaya untuk mendukung tercapainya Sustainable Development Goals (SDGs). Kerangka pemikiran atau logical framework dapat dilihat pada Gambar 1. 


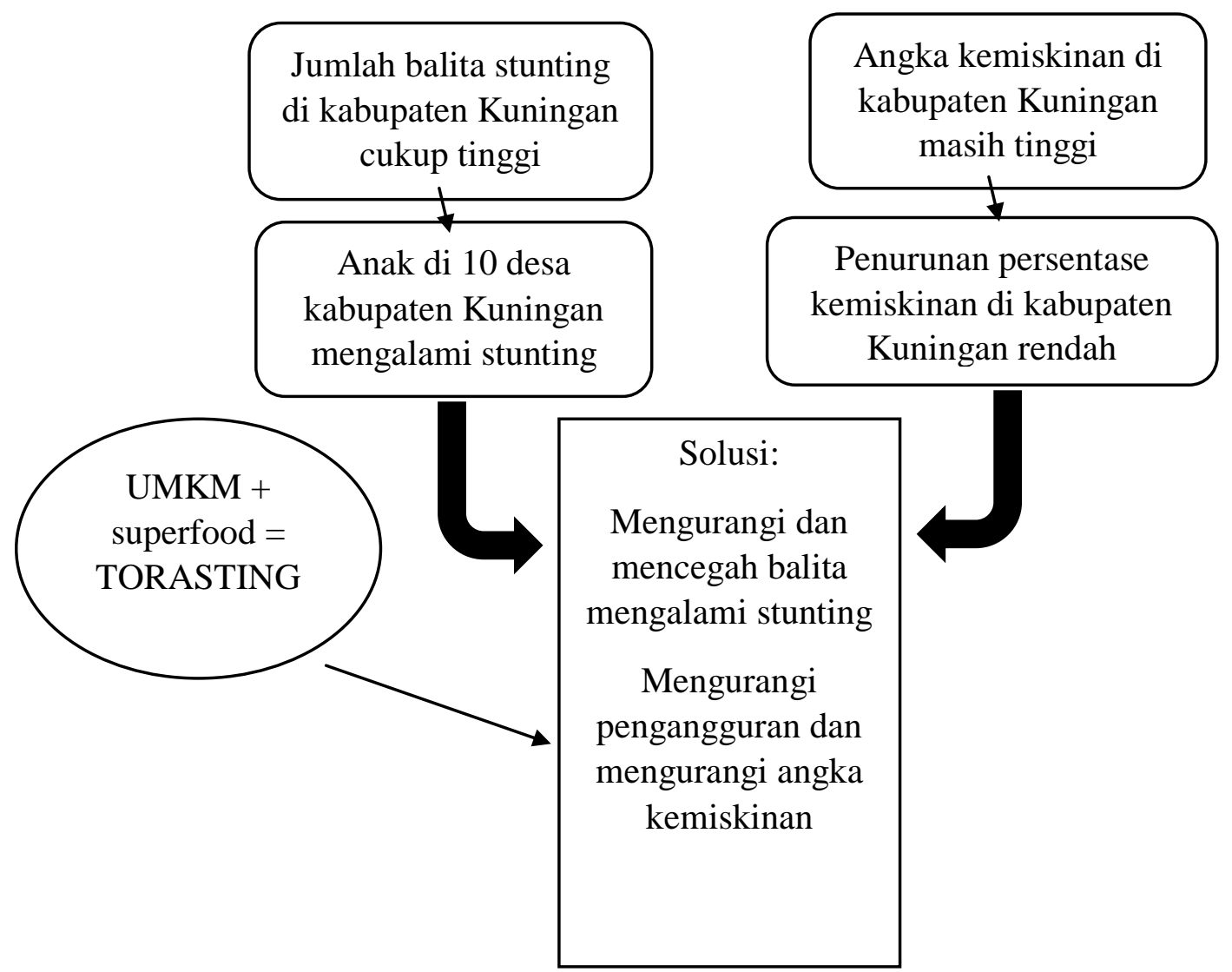

Gambar 1 Kerangka pemikiran penulisan

\section{Hasil dan Pembahasan}

Sistem terpadu antara UMKM dan superfood merupakan upaya untuk mengurangi persentase stunting dan angka kemiskinan di Kuningan. Sistem ini dapat menjadi pembuka jalan usaha dan lapangan pekerjaan karena dapat melibatkan banyak pihak yang tentunya diuntungkan yakni investor atau pemilik usaha, penjajakan keliling dengan menggunakan motor.

\section{Pemilihan bahan utama superfood}

Proses awal dari sistem ini adalah penentuan bahan utama superfood, bahan makanan utama yang ditawarkan dalam karya tulis ini adalah daun kelor karena sebagaimana dari data kandungan gizi yang telah disebutkan di atas daun kelor memiliki kadungan gizi yang sangat tinggi, mudah dan murah untuk didapatkan.

\section{Pengolahan bahan utama superfood}

Agar mudah disukai semua kalangan daun kelor diolah dengan kreatif menjadi makanan-makanan yang banyak disukai oleh semua usia, olahan tersebut diantaranya adalah: es krim daun kelor, puding daun kelor, kerupuk daun kelor, minuman daun kelor, opak daun kelor, makanan pengganti asi (mpasi) daun kelor dan naget daun kelor. Di dalam karya tulis ini penulis memilih tiga menu olahan daun yaitu es krim daun kelor, puding daun kelor dan mpasi daun kelor. 


\section{Menjalin kerjasama dengan PKK dan koperasi desa}

Seusai dengan salah satu tugasnya yaitu menggali, menggerakan dan mengembangkan potensi masyarakat, khususnya keluarga untuk meningkatkan kesejahteraan keluarga sesuai dengan kebijaksanaan yang telah ditetapkan; sistem ini dapat bekerjasama dengan organisasi PKK dan koperasi desa untuk membuat makanan olahan daun kelor serta membangun UMKM dan inovasi desa sebagai bentuk dari meningkatkan kesehatan dan kesejahteraan masyarakat dengan berbasis Tujuan Pembangunan Berkelanjutan (SDGs).

\section{Sistem Distribusi}

Cara mendistribusikan dagangan olahan daun kelor adalah dengan cara berdagang keliling dengan menggunakan sepeda motor karena dapat menjangkau seluruh konsumen sampai ke pelosok desa, selain itu motor adalah kendaraan yang paling tepat karena cepat dan hemat tenaga dengan menggunakan gerobak yang ada di motor menggunakan nama singkatan "torasting" atau motor anti stunting, nama tersebut dipilih karena dijajakannya menggunakan motor, dan menjual makanan sehat pencegah stunting. Selain itu dapat juga menggunakan suara dari speaker toa kecil yang dijadikan ciri khas seperti torasting. jajanan enak, sehat anti stunting

\section{AKG daun kelor}

Salah satu hal yang membuat Kelor menjadi perhatian dunia dan memberikan harapan sebagai tanaman yang dapat menyelamatkan jutaan manusia yang kekurangan gizi, adalah Kelor kaya dengan kandungan nutrisi dan senyawa yang dibutuhkan tubuh. Seluruh bagian tanaman kelor dapat dimanfaatkan untuk penyembuhan, menjaga dan meningkatkan kualitas kesehatan manusia dan terutama sumber asupan gizi keluarga. Bahkan, kandungan kelor diketahui berkali lipat dibandingkan bahan makanan sumber nutrisi lainnya, seperti tampak dalam gambar berikut:

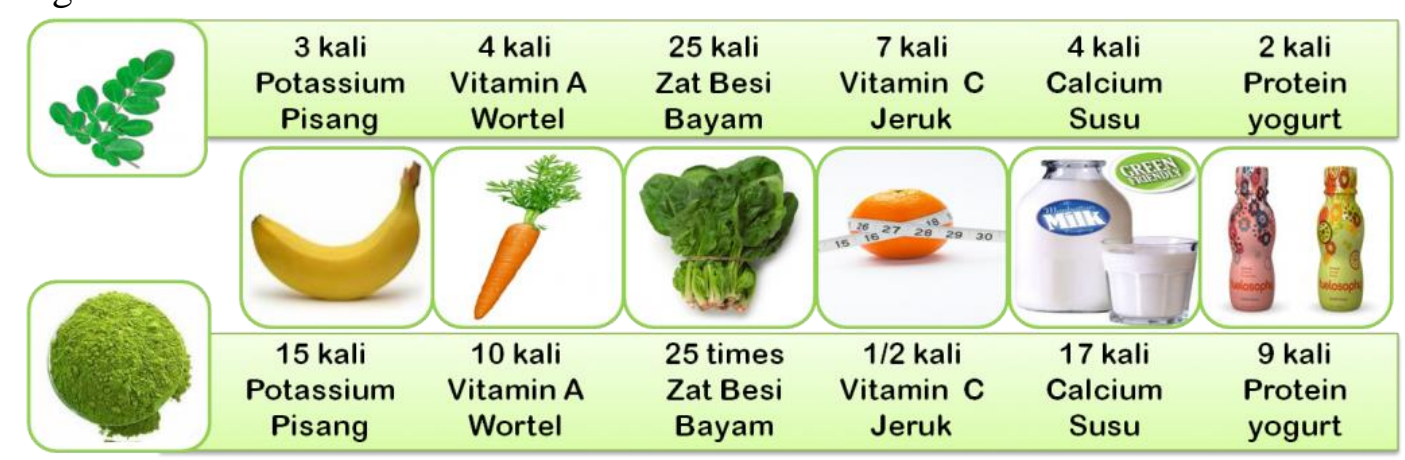

\section{Gambar 3 Perbandingan Nutrisi Daun Kelor Segar dengan Serbuk Daun Kelor}

Sumber: Kelorina.com

Gambar di atas menjelaskan kandungan Potasium pada daun kelor tiga kali lebih banyak dari pisang sedangkan pada serbuk daun kelor lima belas kali lebih banyak; kandungan Vitamin A pada daun kelor empat kali lebih banyak dari wortel sedangkan pada serbuk daun kelor sepuluh kali lebih banyak; kandungan Zat Besi pada daun kelor dua puluh lima kali lebih banyak dari bayam tujuh kali lebih banyak dari jeruk sedangkan pada serbuk daun kelor setengah kali lebih banyak; 
kandungan Kalsium pada daun kelor empat kali lebih banyak dari susu sedangkan pada serbuk daun kelor tujuh belas kali lebih banyak; kandungan Protein pada daun kelor dua kali lebih banyak dari yogurt sedangkan pada serbuk daun kelor sembilan kali lebih banyak.

Kelor mengandung Vitamin A (Alpha \& Beta-carotene), B, B1, B2, B3, B5, B6, B12, C, D, E, K, asam folat, Biotin, dalam jumlah yang berlimpah. Bahkan, berkali lipat dari sumber makanan yang dikenal sebagai sumber nutrisi tinggi. Pada dasarnya, ada dua kelompok vitamin, yaitu: yang larut dalam lemak dan yang larut dalam air. Vitamin A, D, E, dan K, larut dalam lemak sehingga memerlukan lemak agar dapat diserap oleh tubuh. Kelebihan vitamin-vitamin tersebut akan disimpan dalam hati dan lemak tubuh Anda, kemudian digunakan saat diperlukan. Berlebihan mengonsumsi vitamin yang larut dalam lemak dapat membuat Anda keracunan sehingga menyebabkan efek samping seperti mual, muntah, serta masalah hati dan jantung.

Vitamin B kompleks dan C, merupakan vitamin yang larut dalam air. Tubuh Anda menggunakan vitamin-vitamin itu sesuai kebutuhannya, kemudian mengeluarkan kelebihannya melalui urin. Karena vitamin ini tidak disimpan dalam tubuh, risiko keracunan sangat kecil dibandingkan dengan vitamin yang larut dalam lemak, tetapi risiko kekurangan lebih tinggi. Kandungan dalam daun kelor 100gram bisa dilihat di tabel bawah ini.

Tabel 2 Kandungan gizi dalam daun kelor 100 gram

\begin{tabular}{lcc}
\hline \multicolumn{1}{c}{ Kandungan } & Kelor segar & Kelor kering \\
\hline Kalori energy & $92 \mathrm{Kal}$ & $205 \mathrm{Kal}$ \\
\hline Protein & $6,8 \mathrm{gr}$ & $27,1 \mathrm{gr}$ \\
\hline Lemak & $1,7 \mathrm{gr}$ & $2,3 \mathrm{gr}$ \\
\hline Karbohidrat & $12,5 \mathrm{gr}$ & $38,2 \mathrm{gr}$ \\
\hline Serat & $0,9 \mathrm{gr}$ & $19,2 \mathrm{gr}$ \\
\hline Beta Karoten Vitamin A & $6,78 \mathrm{mg}$ & $18,9 \mathrm{mg}$ \\
\hline Vitamin B1 (Tiamin) & $0,06 \mathrm{mg}$ & $2,64 \mathrm{mg}$ \\
\hline Vitamin B2 (riboflavin) & $0,05 \mathrm{mg}$ & $20,5 \mathrm{mg}$ \\
\hline Vitamin B3 (Niasin) & $0.8 \mathrm{mg}$ & $8,2 \mathrm{mg}$ \\
\hline Vitamin C & $220 \mathrm{mg}$ & $17,3 \mathrm{mg}$ \\
\hline Kalsium & & $2003 \mathrm{mg}$ \\
\hline Tembaga & & $0,57 \mathrm{mg}$ \\
\hline Zat besi & & $28,2 \mathrm{mg}$ \\
\hline Magnesium & & $368 \mathrm{mg}$ \\
\hline Fosfor & & $204 \mathrm{mg}$ \\
\hline Kalium & & $1324 \mathrm{mg}$ \\
\hline Seng & & $0.29 \mathrm{mg}$ \\
\hline
\end{tabular}

Sumber: https://ppid.lumajangkab.go.id/file/LEAF-FLATE-SEGO KELORpdf1573609184.pdf 
Setelah dilihat dari tabel di atas mengenai kandungan vitamin dan mineral dari 100 gram daun kelor mempunyai kandungan gizi yang banyak untuk memenuhi kebutuhan gizi di dalam tubuh.

Penghitungan analisis financial dapat menggunakan criteria kelayakan investasi. Kriteria kelayakan investasi digunakan untuk mengetahui atau mengukur manfaat yang diperoleh dan biaya yang dikeluarkan dalam usaha olahan makanan dari tepung daun kelor. Berdasarkan kriteria kelayakan investasi, maka dapat diketahui apakah usaha makanan dari tepung daun kelor layak diusahakan atau tidak. Analisis criteria investasi yang digunakan yakni, NPV (net present value), Net B/C, IRR (internal rate return), PP (payback periods), dan sensivitas. Hasil analisis kriteria investasi disajikan pada Tabel 3.

Tabel 3 Hasil Analisis Kriteria Kelayakan Investasi dalam Usaha Olahan Makanan dari Tepung Daun Kelor

\begin{tabular}{lcc}
\hline \multicolumn{1}{c}{ Kriteria Investasi } & Hasil Analisis & Keterangan \\
\hline NPV (Net Present Value) & 15.499 .300 & Layak \\
Net B/C & 4,85 & Bermanfaat \\
IRR (Internal Rute & $48 \%$ & Layak dan Menguntungkan \\
Return) PP (Payback & 2 tahun 10 bulan 10 hari & Layak \\
Periods) & & \\
\hline Sumber: Santosa dan Imamah 2018 &
\end{tabular}

Sumber: Santosa dan Imamah 2018

Tabel 4 Analisis Sensitivitas Switching Value dengan Kenaikan Bahan Baku Daun Kelor Sebesar 10\%

\begin{tabular}{lcc}
\hline \multicolumn{1}{c}{ Kriteria Investasi } & Hasil Analisis & Keterangan \\
\hline NPV (Net Present Value) & 12.684 .722 & Layak \\
Net B/C & 4,27 & Bermanfaat \\
IRR (Internal Rute & & \\
Return) & $44 \%$ & Layak dan Menguntungkan \\
PP (Payback Periods) & 3 tahun 4 bulan 10 hari & Layak \\
\hline
\end{tabular}

Sumber: Santosa dan Imamah 2018

Berdasarkan tabel 3, dapat dijelaskan sebagai berikut :

a. NPV (Net Present Value)

Nilai NPV usaha olahan makanan dari tepung daun kelor pada tingkat suku bunga 9,96\% sebesar Rp. 15.499.300. Hal ini menunjukkan bahwa nilai NPV lebih besar dari pada nilai nol atau bernilai positif, maka usaha olahan makanan dari tepung daun kelor layak diusahakan.

b. Net B/C

Nilai Net B/C pada usaha olahan makanan dari tepung daun kelor sebesar 4,85. Nilai Net B/C $(4,85)$ lebih besar dari pada 0. Artinya, setiap Rp. 1 biaya yang dikeluarkan dapat menghasilkan $\mathrm{Rp}$ 4,85. Maka, dapat disimpulkan bahwa usaha olahan makanan dari tepung daun kelor memberikan manfaat atau menguntungkan.

c. IRR (Internal Rate Return) 
IRR merupakan salah satu kriteria investasi yang digunakan untuk mengetahui seberapa besar tingkat pengembalian investasi yang ditanamkan usaha olahan makanan dari tepung daun kelor yang diukur dengan suku bunga yang berlaku yaitu 9,96\%. Nilai IRR sebesar 48\%, hal ini menunjukkan bahwa nilai IRR lebih besar dari tingkat suku bunga yang berlaku $(48 \%>9,96 \%)$. Artinya, usaha olahan makanan dari tepung daun kelor layak untuk dijalankan. Selain itu, nilai IRR tersebut juga menunjukkan bahwa olahan makanan dari tepung daun kelor akan tetap layak untuk diusahakan hingga tingkat suku bunga mencapai $48 \%$.

d. PP (Payback Periods)

Nilai PP yaitu sebesar 2,86 yang artinya, usaha olahan makanan dari tepung daun kelor dapat mengembalikan investasi kurun waktu 2 tahun 10 bulan 10 hari yang dilakukan dengan perhitungan kelayakan berdasarkan periode proyek 10 tahun.

e. Sensitivitas Switching Value

Suatu usaha dalam pengelolaan produksi tidak akan lepas dari adanya suatu perubahan khususnya pada biaya produksi, sebab harga bahan-bahan yang digunakan dalam pembuatan olahan makanan dari tepung daun kelor akan mengalami kenaikan atau penurunan diakibatkan oleh permintaan pasar. Analisis sensitivitas digunakan untuk mengetahui seberapa besar pengaruh jika terjadi kenaikan harga bahan baku daun kelor sebesar 10\%. Adapun kriteria kelayakan investasi usaha olahan makanan dari tepung daun kelor dengan kenaikan bahan baku sebesar $10 \%$ dapat dilihat pada Tabel 4 .

Tabel 4, menunjukkan bahwa pada saat bahan baku daun kelor yang digunakan dalam usaha olahan makanan dari tepung daun kelor mengalami kenaikan harga sebesar 10\%, maka nilai NPV mengalami penurunan menjadi Rp. 12.684.722, Net B/C turun menjadi 4,27, dan nilai IRR menjadi 44\%, serta nilai PP semakin lama yaitu menjadi 3 tahun 4 bulan 10 hari. Dalam kondisi ini usaha olahan makanan dari tepung daun kelor masih layak diusahakan.

\section{Kesimpulan}

Sistem terpadu antara UMKM dan superfood merupakan sistem gagasan dari penulis yang menggabungkan antara UMKM dan superfood dari bahan daun kelor yang mudah didapat untuk mengurangi angka kemiskinan di daerah kabupaten Kuningan dengan membuka lapangan pekerjaan untuk berdagang, serta mengurangi persentase stunting yang masih tinggi di Kuningan. Upaya ini juga untuk membantu tercapainya Tujuan Pembangunan Berkelanjutan (SDGs) di kabupaten Kuningan. 
Figih Pratama dan Atin Suhartini

\section{BIBLIOGRAFI}

Duradin, D. (2017). Kebijakan Pemerintah Di Bidang Perikanan Untuk Pelestarian Lingkungan Hidup Dan Kesejahteraan Nelayan. Syntax Literate; Jurnal Ilmiah Indonesia, 2(12), 22-34.

Indonesia, R. (1983). Undang-undang No 5 Tahun 1983 tentang Zona Ekonomi Ekslusif Indonesia. Lembaran Negara RI Tahun.

Mustawan, A. (2018). Anak di 10 Desa mengalami stunting.

Rizali, R., Nurhakim, N., Santoso, E., \& Novianti, Y. S. (2019). Evaluasi Volume Tampung Dari Sump Dengan Persamaan Water Balance. Jurnal Himasapta, 1(01).

Romulus, A. (2017). Peran Hukum Maritim Terhadap Hasil Tangkapan Nelayan Di Wilayah Perbatasan. Syntax Literate; Jurnal Ilmiah Indonesia, 2(5), 9-18. 